\title{
Pengaruh Ketepatan Pengalokasian, Teknologi dan Informasi Perpajakan, dan Diskriminasi Terhadap Penggelapan Pajak (Tax Evasion)
}

\author{
Ika Fitriyanti \\ Achmad Fauzi \\ Diah Armeliza \\ Email:ikafitrianti80@gmail.com
}

Fakultas Ekonomi Universitas Negeri Jakarta

\begin{abstract}
Abstrak
Penelitian ini bertujuan untuk menganalisa pengaruh ketepatan pengalokasian, teknologi dan informasi perpajakan, dan diskriminasi terhadap penggelapan pajak (tax evasion).Populasi penelitian ini adalah wajib pajak orang pribadi yang terdaftar di KPP Pratama Jakarta Sunter.Sampel dalam penelitian ini ditentukan berdasarkan metode convenience sampling, data dikumpulkan dengan pembagian kuisioner.Metode analisis data penelitian yang digunakan adalah regresi linier berganda.Berdasarkan hasil analisis menunjukkan bahwa ketepatan pengalokasian tidak berpengaruh signifikan terhadap penggelapan pajak, teknologi dan informasi perpajakan berpengaruh negatif dan signifikan terhadap penggelapan pajak, dan diskriminasi berpengaruh positif dan signifikan terhadap penggelapan pajak.
\end{abstract}

Keyword: penggelapan pajak, diskriminasi, TI perpajakan, Ketepatan pengalokasian

\section{BAB I}

\section{PENDAHULUAN}

\section{A. Latar Belakang Masalah}

Tidak dapat dipungkiri lagi bahwa pajak menjadi salah satu sumber penerimaan terbesar bagi Indonesia. Penerimaan dari sektor pajak biasanya digunakan oleh pemerintah untuk membiayai keseluruhan pengeluaran negara, baik itu pengeluaran rutin maupun pengeluaran pembangunan yang bertujuan demi meningkatkan kemakmuran dan kesejahteraan rakyatnya. Menyadari akan pentingnya penerimaan dari sektor pajak, maka pemerintah Indonesia setiap tahunnya selalu berusaha untuk meningkatkan sumber penerimaan dalam negeri khususnya dari sektor pajak.

Upaya meminimalkan beban pajak dapat dilakukan oleh wajib pajak dengan berbagai cara, mulai dari yang masih berada dalam koridor peraturan perpajakan sampai dengan yang sudah melanggar koridor peraturan perpajakan. Upaya meminimalkan beban pajak yang masih berada dalam koridor peraturan perpajakan dikenal dengan istilah penghindaran pajak (tax avoidance) sedangkan upaya meminimalkan beban pajak dengan cara yang sudah melanggar koridor peraturan perpajakan dikenal dengan istilah penggelapan pajak (tax evasion).

Jurnal IImiah Wahana Akuntansi
Penggelapan pajak (tax evasion) dapat digambarkan sebagai usaha pengurangan pajak yang dilakukan dengan cara yang illegalatau sudah melanggar peraturan perpajakan sehingga hal ini dapat merugikan negara dan juga akan dikenakan sanksi bagi pihak-pihak yang melakukannya, sedangkan penghindaran pajak (tax avoidance) dapat digambarkan sebagai usaha pengurangan pajak yang dilakukan secaralegal dengan cara memanfaatkan ketentuan-ketentuan di bidang perpajakan secara optimal, seperti pengecualian dan pemotonganpemotongan yang diperkenankan maupun memanfaatkan hal-hal yang belum diatur serta kelemahan-kelemahan yang ada dalam peraturan perpajakan yang berlaku (Suandy, 2009). Meskipun keduanya memiliki tujuan yang sama yaitu ingin meminimalkan beban pajak terutangnya, namun cara yang dilakukan sangatlah bertolak belakang.

Dalam menerapkan penghindaran pajak (tax avoidance) sangat diperlukan pengetahuan serta wawasan yang baik dan luas mengenai bidang perpajakan agar dapat menemukan celah yang tepat untuk mengurangi beban pajak terutangnya tanpa harus melanggar peraturan perundang-undangan perpajakan, sehingga hal ini biasanya hanya bisa dilakukan oleh orang yang kompeten dalam bidang 
perpajakan seperti konsultan pajak. Sulitnya penerapan penghindaran pajak mengakibatkan sebagian besar wajib pajak lebih memilih untuk melakukan tindakan penggelapan pajak. Hal ini dikarenakan mereka masih kurang memiliki pengetahuan yang lebih mengenai perpajakan sehingga tidak menemukan celah yang tepat untuk meminimalkan beban pajak terutangnya tanpa harus melanggar Undang-Undang, selain itu tindakan penggelapan pajak juga dinilai lebih mudah untuk dilakukan meskipun hal tersebut sangat melanggar peraturan perundang-undangan perpajakan.

Saat ini banyak kasus penggelapan pajak yang terjadi di Indonesia. Berdasarkan data yang dihimpun dari CNN Indonesia, bahwa Ditjen Pajak mencatat masih tingginya praktik penggelapan pajak yang dilakukan oleh wajib pajak sepanjang tahun 2014. Hal ini tercermin dari jumlah kasus perpajakan yang naik 280 persen dibandingkan tahun 2013 (www.cnnindonesia.com). Beberapa contoh dari kasus penggelapan pajak yang terjadi di Indonesia yaitu seperti kasus yang menjerat Bahasyim Assifie. Bahasyim diketahui pernah menerima hadiah yang bertentangan dengan kewajibannya atau dalam kata lain telah menerima uang suap senilai Rp. 1 milyar dari wajib pajak bernama Kartini Mulyadi, selain itu Bahasyim juga terbukti melakukan tindak pidana pencucian uang dengan modus pemindahan harta ke beberapa rekening miliknya serta milik istri dan kedua anaknya. Menurut jaksa penuntut umum, selama melaksanakan tugas dan jabatannya sebagai kepala KPP Jakarta VII pada tahun 2002, kepala KPP Koja pada tahun 2006, kepala KPP Palmerah pada tahun 2007, serta Inspektur Bidang Kinerja Kelembagaan Kementerian Negara PPN/Bappennas pada 20082010, Bahasyim dinilai telah melakukan tindak pidana korupsi dan juga pencucian uang (www.beritasatu.com) dan (www.rmol.co).

Selain itu tindakan penggelapan pajak juga pernah dilakukan oleh mantan manajer pajak PT Asian
Agri Group yaitu Suwir Laut alias Liu Che Siu pada tahun 2012 yang terbukti melakukan penggelapan pajak dengan tindak pidana menyampaikan surat pemberitahuan dan/atau keterangan dengan isi tidak benar atau tidak lengkap secara berlanjut selama berturut-turut empat tahun yaitu pada tahun 2002 hingga 2005 terhadap sejumlah 14 perusahaan senilai Rp. 1,259 triliun (www.mongabay.co.id).

Dengan banyaknya contoh kasus penggelapan pajak yang terjadi di Indonesia, semakin membuat wajib pajak tidak patuh dalam melaksanakan kewajiban perpajakannya dengan benar, hal ini dikarenakan mereka semakin tidak percaya dengan petugas pajak dan semakin memiliki pemikiran bahwa uang pajak yang sudah dibayarkannya akan diselewengkan oleh petugas pajak dan tidak dialokasikan dengan tepat.

Penelitian mengenai penggelapan pajak (tax evasion) sendiri telah beberapa kali dilakukan di Indonesia, diantaranya oleh Ayu dan Hastuti (2009), Permatasari (2013), Ardyaksa (2014), Friskianti (2014), Handyani (2014), Silaen (2015), Indriyani et al (2016),Armina dan Tahar (2016), Wahyuningsih (2015), serta Ardi et al (2016). Penelitian-penelitian tersebut membahas mengenai faktor-faktor yang dapat mempengaruhi wajib pajak untuk melakukan penggelapan pajak. Beberapa faktor tersebut diantaranya yaitu ketepatan pengalokasian, teknologi dan informasi perpajakan, serta diskriminasi.

Ketepatan pengalokasian menjadi salah satu faktor yang dapat mempengaruhi wajib pajak untuk melakukan penggelapan pajak. Ketepatan pengalokasian pajak diartikan sebagai pemanfaatan dana pajak yang tercantum dalam APBN dan mendistribusikannya kembali ke masyarakat kedalam bentuk fasilitas umum yang diberikan pemerintah (Sari dan Dwinuri, 2009 dalam Syahrina dan Pratomo, 2014). Oleh karena itu dengan semakin banyaknya dana pajak yang berhasil dikumpulkan atau dibayarkan oleh wajib pajak maka seharusnya fasilitas 
umum yang tersedia untuk masyarakat juga semakin banyak (Ayu dan Hastuti, 2009). Karena pada dasarnya pajak yang telah dibayarkan oleh wajib pajak kepada negara akan kembali juga ke masyarakat seperti dalam bentuk fasilitas umum yang dapat dinikmati oleh masyarakat secara luas.

Masyarakat dalam hal ini wajib pajak pada dasarnya sangat menginginkan pemerintah untuk mengalokasikan hasil penerimaan yang diterima dari sektor pajak dengan tepat dan sebesar-besarnya untuk kesejahteraan rakyat (Permatasari, 2013). Namun, apabila wajib pajak masih merasakan bahwa pemerintah mengalokasikan dana pajaknya dengan tidak tepat maka wajib pajak tersebut akan semakin malas untuk melaksanakan kewajiban perpajakannya dengan benar sehingga hal ini akan memicu wajib pajak untuk melakukan tindakan penggelapan pajak. Hal ini sesuai dengan penelitian yang dilakukan oleh Ardyaksa (2014) yang mengatakan bahwa ketika pengeluaran pemerintah dianggap tidak baik maka kecenderungan wajib pajak untuk melakukan penggelapan pajak akan semakin tinggi.

Teknologi dan informasi perpajakan juga menjadi faktor yang dapat mempengaruhi wajib pajak untuk melakukan penggelapan pajak. Pemerintah dalam hal ini Ditjen Pajak telah melakukan modernisasi pelayanan perpajakan berupa penerapan teknologi dan informasi yang modern dalam bidang perpajakan yang diharapkan dapat meningkatkan kualitas pelayanan serta meningkatkan pula kepatuhan wajib pajak dalam membayar pajak terhutangnya (Permatasari, 2013). Sehingga dengan semakin modernnya fasilitas dalam bidang perpajakan yang telah disediakan oleh pemerintah diharapkan tingkat penggelapan pajak juga akan semakin rendah. Hal ini dikarenakan dengan menggunakan sistem perpajakan yang terhubung langsung dengan DJP, wajib pajak akan semakin sulit untuk memanipulasi data perpajakannya dan juga dapat meminimalisir tingkat kecurangan yang dapat dilakukan antara wajib pajak dan fiskus.
Hal ini sesuai dengan hasil penelitian yang dilakukan oleh Ardyaksa (2014) yang mengatakan bahwa teknologi dan informasi perpajakan berpengaruh negatif terhadap penggelapan pajak. Hal ini mengindikasikan bahwa semakin tinggi dan modern teknologi dan informasi perpajakan maka akan mengurangi tingkat penggelapan pajak. Hasil penelitian dari Permatasari (2013) juga mengatakan bahwa teknologi dan informasi perpajakan berpengaruh negatif dan signifikan terhadap penggelapan pajak. Namun penelitian yang dilakukan oleh Ayu dan Hastuti (2009) dan juga Friskianti (2014) justru memiliki hasil penelitian yang berbeda, hasil penelitian mereka mengatakan bahwa teknologi dan informasi perpajakan tidak berpengaruh terhadap penggelapan pajak (tax evasion).

Faktor selanjutnya yang dapat mempengaruhi wajib pajak untuk melakukan penggelapan pajak yaitu diskriminasi. Diskriminasi merupakan perbedaan perlakuan yang terjadi pada perorangan atau kelompok yang didasarkan pada perbedaan agama, ras, etnik, budaya, jenis kelamin, bahasa, dan aspek kehidupan yang lain. Diskriminasi dalam hal perpajakan dapat berupa peraturan perpajakan yang tidak adil, dalam artian peraturan tersebut menguntungkan pihak-pihak tertentu, ataupun diskriminasi dari segi perlakuan terhadap seluruh wajib pajak (Silaen, 2015). Contoh dari tindakan diskriminasi dalam perpajakan yaitu berupa peraturan yang menegaskan bahwa zakat diperbolehkan sebagai pengurang penghasilan. Tentu hal dianggap sebagai tindakan diskriminasi bagi kaum yang beragama non muslim. Menurut Yolanda, et al (2016), diskriminasi menjadi faktor yang dapat mempengaruhi wajib pajak dalam melakukan penggelapan pajak sehingga penggelapan pajak dapat terjadi dikarenakan adanya diskriminasi yang dirasakan oleh wajib pajak.

Penelitian yang dilakukan oleh Ardi et al (2016) mengatakan bahwa diskriminasi berpengaruh positif terhadap tindakan penggelapan pajak. Hal yang sama 
juga dinyatakan oleh Silaen (2015) yang juga mengatakan bahwa diskriminasi berpengaruh terhadap etika penggelapan pajak. Namun penelitian yang dilakukan oleh Handyani (2014) dan Armina dan Tahar (2016) justru mengatakan bahwa diskriminasi tidak berpengaruh terhadap tindakan penggelapan pajak.

Dari pemaparan hasil penelitian diatas, terlihat bahwa masih adanya perbedaan hasil antar variabelvariabel independen yang digunakan dalam penelitian ini sehingga peneliti termotivasi untuk melakukan penelitian kembali dengan tujuan untuk mengkonfirmasi ulang penelitian sebelumnya serta memberikan bukti empiris baru mengenai pengaruh dari ketepatan pengalokasian, teknologi dan informasi perpajakan, dan diskriminasi terhadap penggelapan pajak.

Berdasarkan latar belakang yang sudah diuraikan diatas, maka penelitian ini mengambil judul "Pengaruh Ketepatan Pengalokasian, Teknologi Dan Informasi Perpajakan, dan Diskriminasi Terhadap Penggelapan Pajak (Tax Evasion)”

\section{B. Identifikasi Masalah}

Berdasarkan latar belakang masalah diatas, dapat diidentifikasikan beberapa masalah pada penelitian ini, antara lain:

1. Masyarakat dalam hal ini wajib pajak masih merasa bahwa pengalokasian pengeluaran pemerintah dari sektor pajak masih kurang tepat pengalokasiannya.

2. Masih rendahnya penggunaan teknologi dan informasi perpajakan oleh wajib pajak khususnya wajib pajak orang pribadi.

3. Wajib pajak masih merasakan adanya tindakan diskriminasi dalam bidang perpajakan.

4. Penggelapan pajak di Indonesia sudah banyak terjadi, hal ini terbukti dengan banyaknya kasuskasus penggelapan pajak seperti kasus yang dilakukan oleh Bahasyim Assifie, David Kenny Naftali, dan Suwir Laut.

\section{Pembatasan Masalah}

Adapun batasan masalah dalam penelitian ini yaitu:

1. Penelitian ini hanya meneliti variabel independen yaitu ketepatan pengalokasian, teknologi dan informasi perpajakan, serta diskriminasi dengan metode pengambilan data menggunakan kuisioner.

2. Sampel penelitian yang digunakan adalah wajib pajak orang pribadi yang terdaftar pada KPP Pratama Jakarta Sunter.

\section{Perumusan Masalah}

Berdasarkan permasalahan yang sudah dijelaskan diatas, maka penelitian ini merumuskan pertanyaan sebagai berikut :

1. Apakah ketepatan pengalokasian berpengaruh terhadap penggelapan pajak (tax evasion)?

2. Apakah teknologi dan informasi perpajakan berpengaruh terhadap penggelapan pajak (tax evasion)?

3. Apakah diskriminasi berpengaruh terhadap penggelapan pajak (tax evasion)?

\section{BAB II}

\section{KAJIAN TEORETIK}

\section{A. Deskripsi Konseptual}

1. Pajak

Definisi pajak menurut pasal 1 angka 1 UU KUP menyebutkan bahwa pajak adalah kontribusi wajib kepada negara yang terutang oleh orang pribadi atau badan yang bersifat memaksa berdasarkan undang-undang, dengan tidak mendapatkan imbalan secara langsung dan digunakan untuk keperluan negara dan bagi sebesar-besarnya kemakmuran rakyat (Agoes dan Trisnawati, 2013:6).

\section{Penggelapan Pajak}


Penggelapan pajak (tax evasion) merupakan usaha meringankan beban pajak dengan cara yang melanggar undang-undang (Mardiasmo, 2011:9).

Menurut Hasanah dan Pahala (2015:8), tindakan penggelapan pajak dapat berupa :

a. Tidak memenuhi kewajiban penyampaian SPT atau menyampaikan SPT tidak tepat waktu.

b. Tidak mengisi SPT dengan benar dan lengkap.

c. Tidak menyetorkan pajak yang telah dipotong atau telah dipungut.

d. Membuat faktur pajak fiktif.

e. Membuat pembukuan berganda (double bookkeeping).

f. Tidak mendaftarkan diri sebagai wajib pajak, menyalahgunakan NPWP, dan sebagainya

\section{Ketepatan Pengalokasian}

Ketepatan pengalokasian pajak adalah pemanfaatan dana pajak yang tercermin dalam APBN dan mendistribusikannya kembali ke masyarakat ke dalam bentuk fasilitas umum yang diberikan pemerintah (Sari dan Dwinuri, 2009 dalam Syahrina dan Pratomo, 2014).

Oleh karena itu seharusnya dengan adanya pajak maka ketersediaan fasilitas umum akan semakin banyak (Ayu dan Hastuti, 2009). Karena pada dasarnya pajak yang telah dibayarkan oleh wajib pajak kepada negara akan kembali juga ke masyarakat seperti dalam bentuk fasilitas umum yang dapat dinikmati oleh masyarakat secara luas, seperti fasilitas transportasi yang lebih nyaman dan juga murah, pembangunan jalan tol yang dapat mengurangi kemacetan, fasilitas pendidikan, fasilitas kesehatan, dan lain sebagainya.

Dengan demikian masyarakat sangat menginginkan pemerintah untuk mengalokasikan hasil penerimaan yang diterima dari sektor pajak dengan tepat dan sebesar-besarnya untuk kesejahteraan rakyat (Permatasari dan Laksito,
2013). Namun, apabila wajib pajak masih merasakan bahwa pemerintah mengalokasikan dana pajaknya dengan tidak tepat maka wajib pajak tersebut akan semakin malas untuk melaksanakan kewajiban perpajakannya dengan benar sehingga hal ini akan memicu wajib pajak untuk melakukan tindakan penggelapan pajak.

\section{Teknologi dan Informasi Perpajakan}

Teknologi dan informasi perpajakan merupakan penggunaan sarana dan prasarana perpajakan dengan memanfaatkan ilmu dan perkembangan teknologi serta informasi dibidang perpajakan untuk meningkatkan kualitas pelayanan perpajakan terhadap wajib pajak yang akan memenuhi kewajiban perpajakannya (Silaen, 2015).

Dengan demikian, modernisasi layanan perpajakan yang telah dilakukan oleh pemerintah diharapkan dapat meningkatkan kualitas pelayanan sehingga dapat meningkatkan pula kepatuhan wajib pajak dalam membayar pajak (Permatasari dan Laksito, 2013).

Sehingga dengan semakin tinggi dan modern teknologi dan informasi perpajakan yang digunakan oleh pemerintah diharapkan akan semakin rendah pula tindakan penggelapan pajak yang dilakukan oleh wajib pajak (Permatasari dan Laksito, 2013).

\section{Diskriminasi}

Diskriminasi adalah perbedaan perlakuan yang terjadi pada perorangan atau kelompok yang didasarkan pada perbedaan agama, ras, etnik, budaya, jenis kelamin, bahasa, dan aspek kehidupan yang lain (Silaen, 2015).

Saat ini wajib pajak masih merasakan adanya tindakan diskriminasi dalam bidang perpajakan, seperti dengan adanya peraturan yang dianggap mendiskriminasi bagi suatu golongan.Salah satu 
peraturan yang dinilai sebagai bentuk diskriminasi yaitu Peraturan Pemerintah Nomor 60 Tahun 2010 tentang zakat atau sumbangan keagamaan yang sifatnya wajib yang dapat dikurangkan dari penghasilan bruto. Adanya peraturan tersebut dianggap hanya menguntungkan wajib pajak yang beragama Islam karena zakat diperbolehkan sebagai pengurang pajak.Selain itu Peraturan Pemerintah Nomor 46 Tahun 2013 tentang pajak penghasilan atas penghasilan dari usaha yang diterima atau diperoleh wajib pajak yang memiliki peredaran bruto tertentu.Dimana pajak final dikenakan sebesar $1 \%$ terhadap penghasilan bruto juga dinilai sebagai bentuk diskriminasi karena banyak merugikan pengusaha kecil menengah yang belum mapan dalam usahanya (Indriyani et al, 2016).

Oleh sebab itu dengan adanya peraturan perpajakan yang dianggap sebagai bentuk diskriminasi oleh wajib pajak maka wajib pajak akan semakin termotivasi untuk melakukan tindakan penggelapan pajak.

\section{B. Hasil Penelitian yang Relevan}

Penelitian yang dilakukan oleh Ayu dan Hastuti (2009) mengatakan bahwa ketepatan pengalokasian pengeluaran pemerintah yang bersumber dari pajak berpengaruh negatif terhadap penggelapan pajak. Kemudian menurut Permatasari dan Laksito (2013) juga mengatakan bahwa ketepatan pengalokasian pengeluaran pemerintah berpengaruh negatif dan bersifat signifikan terhadap penggelapan pajak. Namun penelitian yang dilakukan oleh Wahyuningsih (2015) mengatakan yang sebaliknya, ketepatan pengalokasian pengeluaran pemerintah tidak berpengaruh secara parsial terhadap penggelapan pajak.

Penelitian yang dilakukan oleh Permatasari dan Laksito (2013) mengatakan bahwa teknologi dan informasi perpajakan berpengaruh secara negatif dan signifikan terhadap penggelapan pajak.Hasil penelitian dari Ardyaksa dan Kiswanto (2014) juga mengatakan bahwa teknologi dan informasi perpajakan berpengaruh negatif terhadap penggelapan pajak. Namun penelitian yang dilakukan oleh Ayu dan Hastuti (2009) dan juga Friskianti (2014) justru memiliki hasil penelitian yang berbeda. Hasil penelitian mereka mengatakan bahwa teknologi dan informasi perpajakan tidak berpengaruh terhadap penggelapanpajak (tax evasion).

Penelitian yang dilakukan oleh Ardi et al (2016) mengatakan bahwa diskriminasi berpengaruh positif terhadap tindakan penggelapan pajak. Dan menurut Silaen (2015) juga mengatakan bahwa diskriminasi berpengaruh terhadap etika penggelapan pajak. Namun penelitian yang dilakukan oleh Handyani dan Cahyonowati (2014) dan Armina dan Tahar (2016) justru mengatakan bahwa diskriminasi tidak berpengaruh terhadap tindakan penggelapan pajak.

\section{Kerangka Teoretik}

Ketepatan pengalokasian memiliki pengaruh terhadap penggelapan pajak. Hal ini didasarkan pada hasil bukti empiris dari penelitian yang dilakukan oleh Permatasari dan Laksito (2013) yang mengatakan bahwa ketepatan pengalokasian pengeluaran pemerintah berpengaruh negatif dan signifikan terhadap penggelapan pajak sehingga ketika pengeluaran pemerintah dianggap tidak tepat atau tidak baik maka kecenderungan wajib pajak untuk melakukan penggelapan pajak akan semakin tinggi.

Pengaruh teknologi dan informasi perpajakan terhadap penggelapan pajak yaitu dengan semakin tinggi dan modernnya teknologi dan informasi perpajakan yang digunakan oleh pemerintah, diharapkan akan semakin rendah pula tindakan penggelapan pajak yang akan dilakukan oleh wajib 
pajak (Permatasari dan Laksito, 2013).

Sementara itu pengaruh diskriminasi terhadap penggelapan pajak yaitu dengan masih adanya kebijakan yang ditentukan hanya menguntungkan sebagian pihak saja, maka akan timbul penentangan dari masyarakat yang mengakibatkan tindakan

penggelapan pajak (Ardi et al, 2016).

Berdasarkan penjelasan diatas, maka dapat disimpulkan dalam gambar sebagai berikut:

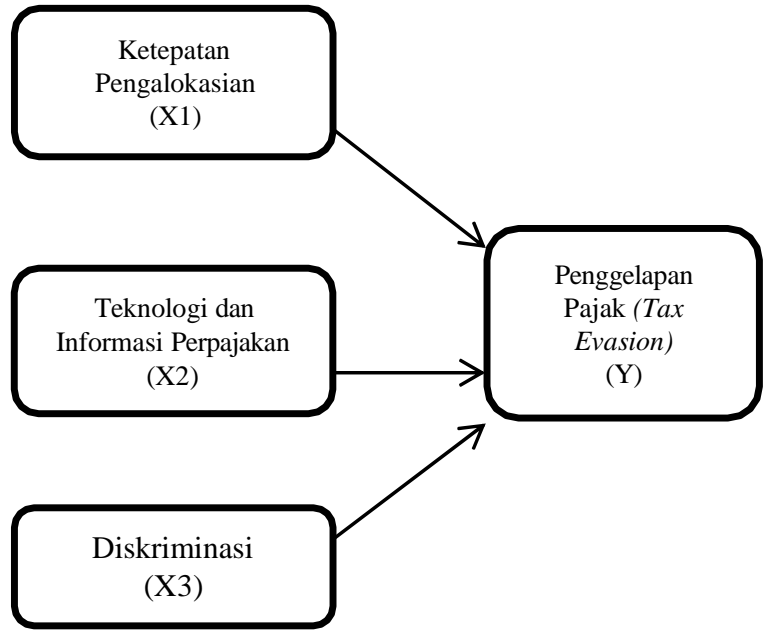

\section{Perumusan Hipotesis}

$\mathrm{H}_{1}$ :Ketepatan pengalokasian berpengaruh

terhadap penggelapan pajak.

$\mathrm{H}_{2}$ : Teknologi dan informasi perpajakan berpengaruh terhadap penggelapan pajak.

$\mathbf{H}_{3}$ :Diskriminasi berpengaruh terhadap penggelapan pajak

\section{BAB III}

\section{METODOLOGI PENELITIAN}

\section{A. Tujuan Penelitian}

Berdasarkan perumusan masalah yang telah dijelaskan pada Bab 1, maka tujuan dari penelitian adalah:

1. Mengetahui pengaruh teknologi dan informasi perpajakan terhadap penggelapan pajak (tax evasion).

2. Mengetahui pengaruh ketepatan pengalokasian terhadap penggelapan pajak (tax evasion).
3. Mengetahui pengaruh diskriminasi terhadap penggelapan pajak (tax evasion).

\section{B. Objek dan Ruang Lingkup Penelitian}

Dalam penelitian ini, objek yang diteliti yaitu Wajib Pajak Orang Pribadi.Sedangkan ruang lingkup penelitian mengenai pengaruh teknologi dan informasi perpajakan, ketepatan pengalokasian, dan diskriminasi terhadap penggelapan pajak adalah Wajib Pajak Orang Pribadi yang terdaftar pada Kantor Pelayanan Pajak (KPP) Pratama Jakarta Sunter.

\section{Metode Penelitian}

Metode yang digunakan dalam penelitian ini adalah metode kuantitatif dengan pendekatan regresi linier berganda.Penelitian dilakukan dengan menggunakan data primer. Pengumpulan data dilakukan dengan cara memberikan kuisioner kepada Wajib Pajak Orang Pribadi yang terdaftar di KPP

Jurnal IImiah Wahana Akuntansi 
Pratama Jakarta Sunter sebagai responden dalam penelitian ini.

\section{Populasi dan Sampel}

\section{Populasi}

Populasi adalah wilayah generalisasi yang terdiri atas obyek/subyek yang mempunyai kualitas dan karakteristik tertentu yang ditetapkan oleh peneliti untuk dipelajari dan kemudian ditarik kesimpulannya (Sugiyono, 2014:61).Adapun populasi dalam penelitian ini adalah Wajib Pajak Orang Pribadi yang terdaftar di KPP Pratama Jakarta Sunter.

\section{Sampel}

Sampel adalah bagian dari jumlah dan karakteristik yang dimiliki oleh populasi (Sugiyono, 2014:62).Metode pengambilan sampel dilakukan dengan menggunakan metode non probability sampling dengan teknik convenience sampling. Convenience sampling yaitu penarikan sampel berdasarkan keinginan peneliti sesuai dengan tujuan penelitian dan anggota populasi tersebut tidak mempunyai peluang yang sama untuk terpilih menjadi sampel (Supriyadi, 2011:17).Teknik pemilihan sampel ini dipilih karena pertimbangan lokasi yang mudah untuk dijangkau sehingga dapat memudahkan peneliti dalam penggumpulan sampel yang akandigunakan dalam penelitian ini. Adapun sampel yang diambil dalam penelitian ini yaitu Wajib Pajak Orang Pribadi yang terdaftar pada KPP Pratama Jakarta Sunter. Pengambilan sampel dilakukan dengan metode convenience sampling dengan penentuan jumlah sampelnya menggunakan rumus slovin sebagai berikut:

$$
\mathrm{n}=
$$

Dalam hal ini:

$$
\begin{aligned}
& \mathrm{n}=\text { Jumlah sampel } \\
& \mathrm{N}=\text { Jumlah populasi } \\
& \mathrm{e}=\text { Batas toleransi kesalahan }(10 \%)
\end{aligned}
$$

Berdasarkan pengambilan sampel yang dilakukan dengan metode convenience sampling dengan menggunakan rumus slovin, dari jumlah populasi wajib pajak orang pribadi yang terdaftar di KPP Pratama Jakarta Sunter sebanyak 51.735 wajib pajak, maka hasil perhitungan sampelnya adalah sebesar 99,98 dan dibulatkan menjadi 100 wajib pajak. Jadi, sampel yang diambil yaitu 100 wajib pajak orang pribadi yang terdaftar pada

KPP Pratama Jakarta Sunter.

\section{Operasionalisasi Variabel Penelitian}

Penelitian ini menggunakan empat variabel, yang terdiri dari satu variabel dependen dan tiga variabel independen. Untuk memberikan pemahaman yang lebih spesifik, maka variabel-variabel dalam penelitian ini didefinisikan secara operasional, sebagai berikut:

\section{Variabel Dependen}

Variabel dependen atau sering disebut juga variabel terikat merupakan variabel yang dipengaruhi atau yang menjadi akibat, karena adanya variabel bebas (Sugiyono, 2011:4).Pada penelitian ini yang menjadi variabel dependen adalah penggelapan pajak (tax evasion).

a. Definisi Konseptual

Penggelapan pajak (tax evasion) merupakan usaha yang dilakukan wajib pajak (entah berhasil atau tidak) untuk mengurangi atau sama sekali menghapus utang pajak yang dilakukan dengan melanggar hukum yang ada dalam undang-udang (Hasanah dan Pahala, 2015:8).

b. Definisi Operasional

Adapun indikator yang digunakan untuk mengukur penggelapan pajak (tax evasion) mengacu pada penelitian yang dilakukan oleh Yossi Friskianti (2014), Nuramalia Hasanah dan Indra Pahala (2015:8), dan Mohammad Zain (2008:51) yaitu:

1. Tidak menyampaikan SPT, 
2. Menyampaikan SPT dengan tidak benar,

3. Tidak mendaftarkan diri atau menyalahgunakan NPWP atau pengukuhan PKP,

4. Tidak menyetorkan pajak yang telah dipungut atau dipotong,

5. Berusaha menyuap fiskus.

\section{Variabel Independen}

Variabel independen atau sering juga disebut variabel bebas merupakan variabel yang mempengaruhi atau yang menjadi sebab perubahannya atau timbulnya variabel dependen (Sugiyono, 2011:4). Pada penelitian ini terdapat 3 (tiga) variabel independen, antara lain:

\section{a. Ketepatan Pengalokasian}

1) Definisi Konseptual

Ketepatan pengalokasian pajak adalah pemanfaatan dana pajak yang tercermin dalam APBN dan mendistribusikannya kembali ke masyarakat ke dalam bentuk fasilitas umum yang diberikan pemerintah (Sari dan Dwinuri, 2009 dalam Syahrina dan Pratomo, 2014).

2) Definisi Operasional

Pada variabel ketepatan pengalokasian in $\mathrm{i}$ diukur dengan menggunakan skala likert yang menggunakan 5 poin penilaian, yaitu: (1) tidak setuju, (2) kurang setuju, (3) netral, (4) setuju, (5) sangat setuju. Adapun indikator yang digunakan untuk mengukur ketepatan pengalokasian mengacu pada penelitian yang dilakukan oleh Theo Kusuma Ardyaksa (2014) dan Stephana Dyah Ayu (2009), yaitu:

1. Prinsip manfaat dari penggunaan uang yang bersumber dari pajak

2. Pendistribusian dana yang bersumber dari pajak

\section{b. Teknologi dan Informasi Perpajakan}

1) Definisi Konseptual
Teknologi dan informasi perpajakan didefinisikan sebagai fasilitas perpajakan berupa penerapan teknologi dan informasi perpajakan yang modern yang digunakan oleh pemerintah dan diperuntukkan kepada wajib pajak dengan tujuan agar mempermudah wajib pajak dalam melaksanakan kewajiban perpajakannya (Permatasari dan Laksito, 2013).

2) Definisi Operasional

Pada variabel teknologi dan informasi perpajakan ini diukur dengan menggunakan skala likert yang menggunakan 5 poin penilaian, yaitu: (1) tidak setuju, (2) kurang setuju, (3) netral, (4) setuju, (5) sangat setuju. Adapun indikator yang digunakan untuk mengukur teknologi dan informasi perpajakan mengacu pada penelitian yang dilakukan oleh Auliya Ulfa (2015), Theo Kusuma Ardyaksa (2014), dan Yossi Friskianti (2014), yaitu:

1. Ketersediaan teknologi yang berkaitan dengan perpajakan

2. Memadainya teknologi yang berkaitan dengan perpajakan

3. Akses informasi perpajakan yang mudah

4. Pemanfaatan fasilitas teknologi informasi perpajakan

\section{c. Diskriminasi}

1) Definisi Konseptual

Berdasarkan Undang-Undang No. 39 Tahun 1999 tentang Hak Asasi Manusia Pasal 1 ayat (3), diskriminasi adalah setiap pembatasan, pelecehan, atau pengucilan yang langsung maupun tidak langsung didasarkan perbedaan manusia atas dasar agama, suku, ras, etnik, kelompok, golongan, status sosial, status ekonomi, jenis kelamin, bahasa, dan 
keyakinan politik yang berakibat pengangguran, penyimpangan atau penghapusan pengakuan, pelaksaanaan atau penggunaan hak asasi manusia dan kebebasan dasar dalam kehidupan, baik individual maupun kolektif dalam bidang politik, ekonomi, hukum, sosial, budaya, dan aspek kehidupan yang lain (Sariani et al, 2016).

2) Definisi Operasional

Pada variabel diskriminasi ini diukur dengan menggunakan skala likert yang menggunakan 5 poin penilaian, yaitu: (1) tidak setuju, (2) kurang setuju, (3) netral, (4) setuju, (5) sangat setuju. Adapun indikator yang digunakan untuk mengukur diskriminasi mengacu pada penelitian yang dilakukan oleh Charles Silaen (2015), Devi Martha Ardi (2016) dan Eka Nilam Armina (2016), yaitu:

1. Pendiskriminasian atas agama, ras, kebudayaan, dan keanggotaan kelaskelas sosial.

2. Pendiskriminasian terhadap hal-hal yang disebabkan oleh manfaat perpajakan.

\section{Teknik Analisis Data}

\section{Analisis Statistik Deskriptif}

Statistik deskriptif digunakan untuk memberikan gambaran atau deskripsi suatu data yang dilihat dari rata-rata (mean), standar deviasi, variance, maksimum, minimum, kurtosis dan skewness (kemencengan data) (Ghozali, 2011:16).

\section{Uji Kualitas Data}

\section{a. Uji Validitas Data}

Uji validitas digunakan untuk mengukur sah atau valid tidaknya suatu kuisioner. Suatu kuisioner dikatakan valid jika pertanyaan pada kuisioner mampu untuk mengungkapkan sesuatu yang akan diukur oleh kuisioner tersebut (Ghozali, 2011:135). Menurut Ghozali, mengukur tingkat validitas dapat dilakukan dengan dua cara, yaitu:

1) Melakukan korelasi antara skor butir pertanyaan dengan total skor konstruk atau variabel.

2) Menghitung korelasi antara skor masing-masing butir pertanyaan dengan total skor.

\section{b. Uji Reliabilitas}

Reliabilitas adalah alat untuk mengukur suatu kuisioner yang merupakan indikator dari variabel atau konstruk.Suatu kuisioner dikatakan reliabel atau handal jika jawaban seseorang terhadap pertanyaan adalah konsisten atau stabil dari waktu ke waktu (Ghozali, 2011:132).

\section{Uji Asumsi Klasik}

Uji asumsi klasik digunakan dalam penelitian ini untuk menguji apakah data telah memenuhi asumsi klasik atau tidak.Pengujian asumsi klasik yang dilakukan yaitu uji normalitas, uji multikolinieritas, dan uji heteroskedastisitas.

\section{a. Uji Normalitas}

Uji normalitas bertujuan untuk menguji apakah dalam model regresi, variabel terikat, dan variabel bebas keduanya mempunyai distribusi normal ataukah tidak.Model regresi yang baik adalah memiliki distribusi data normal atau mendekati normal. Untuk menguji apakah distribusi data normal atau tidak dapat dilakukan dengan dua cara, yaitu dengan melihat normal probability plot yang membandingkan distribusi kumulatif dari data sesungguhnya dengan distribusi kumulatif dari distribusi normal, serta dapat juga dilakukan dengan uji statistik. Test statistik sederhana yang dapat dilakukan adalah 
berdasarkan nilai kurtosis atau skewness (Ghozali, 2011:74-76).

\section{b. Uji Multikolinieritas}

Uji multikolonieritas ini bertujuan untuk menguji apakah model regresi ditemukan adanya korelasi antar variabel bebas (independen).Model regresi yang baik seharusnya tidak terjadi korelasi diantara variabel bebas.Untuk mendeteksi ada atau tidaknya multikolonieritas didalam model regresi dilihat dari besaran VIF (Variance Inflation Factor) dan nilai Tolerance.Tolerance mengukur variabilitas variabel bebas terpilih yang tidak dijelaskan oleh variabel bebas lainnya. Jadi nilai tolerance yang rendah sama dengan nilai VIF yang tinggi (karena $\mathrm{VIF}=1 /$ Tolerance) dan menunjukkan adanya kolonieritas yang tinggi. Nilai cut off yang umum dipakai adalah nilai tolerance 0,10 atau sama dengan nilai VIF diatas 10(Ghozali, 2011:57).

\section{c. Uji Heteroskedastisitas}

Uji heteroskedastisitas bertujuan untuk menguji apakah dalam model regresi terjadi ketidaksamaan variance dari residual satu pengamatan ke pengamatan yang lain. Jika variance dari residual satu pengamatan ke pengamatan yang lain tetap, maka disebut Homoskedastisitas dan jika berbeda disebut Heteroskedastisitas. Model regresi yang baik adalah yang homoskedastisitas atau jika tidak terjadi heteroskedastisitas (Ghozali, 2011:69). Untuk mendeteksi ada atau tidaknya heteroskedastisitas dapat dilakukan dengan melihat grafik plot antara nilai prediksi variabel terikat (ZPRED) dengan residualnya (SRESID).

\section{Analisis Regresi Linier Regresi Berganda}

Analisis yang digunakan dalam penelitian ini adalah analisis regresi linier berganda, yaitu suatu model yang digunakan untuk menganalisis atau mengukur kekuatan hubungan antara dua variabel atau lebih, dan juga menunjukkan arah hubungan antara variabel dependen dengan variabel independen. Model ini digunakan untuk menguji apakah ada hubungan sebab akibat antara kedua variabel untuk meneliti seberapa besar pengaruh antara variabel independen, yaitu teknologi dan informasi perpajakan, ketepatan pengalokasian, dan diskriminasi berpengaruh terhadap variabel dependen, yaitu penggelapan pajak (tax evasion). Persamaan regresi dalam penelitian ini adalah sebagai berikut:

\section{$Y=a+\beta_{1} X_{1}+\beta_{2} X_{2}+\beta_{3} X_{3}+e$}

Dimana:

$\mathrm{Y}=$ Penggelapan pajak (tax evasion)

$\mathrm{a}=$ Bilangan konstanta

$\beta=$ Koefisien regresi

$X_{1}=$ Teknologi dan informasi perpajakan

$\mathrm{X}_{2}=$ Ketepatan pengalokasian

$\mathrm{X}_{3}=$ Diskriminasi

$\mathrm{e}=$ error yang ditolerir

\section{Uji Hipotesis}

Secara statistik, model regresi dapat diukur melalui nilai koefisien determinasi $\left(\mathrm{R}^{2}\right)$, nilai statistik t dan nilai statistik F. Apabila nilai uji statistiknya berada di daerah kritis (Ha diterima) maka perhitungan tersebut signifikan. Sebaliknya bila nilai uji statistiknya berada di daerah (Ha ditolak) maka perhitungannya tidak signifikan.

\section{a. Uji Statistik t}

Uji statistik t pada dasarnya menunjukkan seberapa jauh pengaruh satu variabel penjelas/independen secara individual dalam menerangkan variasi variabel dependen.

\section{b. Uji Statistik F}

Uji statistik $F$ pada dasarnya menunjukkan apakah semua variabel bebas yang dimasukkan 
dalam model mempunyai pengaruh secara bersama-sama terhadap variabel terikat/dependen. Menurut Ghozali (2011:45)

\section{c. Uji Koefisien Determinasi(Adjusted $\boldsymbol{R}^{2}$ )}

Koefisien determinasi $\left(\mathrm{R}^{2}\right)$ pada intinya digunakan untuk mengukur seberapa jauh kemampuan model dalam menerangkan variasi variabel dependen. Nilai koefisien determinasi adalah diantara nol dan satu. Jika pada suatu model nilai $\mathrm{R}^{2}$ kecil, berarti kemampuan variabelvariabel independen dalam menjelaskan variasi variabel dependen amat terbatas. (Ghozali, 2011:45)

\section{BAB IV}

\section{HASIL PENELITIAN DAN PEMBAHASAN}

\section{A. Pengujian Hipotesis}

\section{Uji Kualitas Data}

\section{a. Uji Validitas}

Uji validitas digunakan untuk mengukur sah atau valid tidaknya suatu kuisioner. Suatu kuisioner dikatakan valid jika pertanyaan pada kuisioner mampu untuk mengungkapkan sesuatu yang akan diukur oleh kuisioner tersebut (Ghozali, 2011:135).

Jumlah responden yang menjadi subyek penelitian berkaitan dengan partisipasinya dalam penelitian ini adalah Wajib Pajak Orang Pribadi berjumlah 20 orang yang dilakukan penyebaran kuesioner di KPP Pratama Jakarta Kelapa Gading pada bulan April 2017.

Dengan menggunakan uji dua sisi (twotailed) dengan taraf signifikasi 5\% maka nilai $\mathrm{r}_{\text {tabel }}$ dalam penelitian ini adalah 0,444.Item pernyataan dinyatakan valid jika nilai $r_{\text {hitung }}>$ dari $\mathrm{rt}_{\mathrm{abel}}$.

Dari hasil uji validitas terhadap pernyataan variabel ketepatan pengalokasian diketahui dari
10 pernyataan yang diuji tidak terdapat pernyataan yang tidak valid/digugurkan.Selanjutnya dari hasil uji validitas terhadap pernyataan variabel teknologi dan informasi perpajakan diketahui dari 12 pernyataan yang diuji tidak terdapat pernyataan yang tidak valid/digugurkan.Sementara itu dari hasil uji validitas terhadap pernyataan variabel diskriminasi diketahui dari 10 pernyataan yang diuji terdapat 9 pernyataan yang valid dan 1 pernyataan yang tidak valid.Dari 10 pernyataan diketahui bahwa pernyataan 9 memiliki $r_{\text {hitung }}$ lebih rendah dari $r_{\text {tabel }}$ dengan nilai 0,430 . Selanjutnya dari hasil uji validitas terhadap pernyataan variabel penggelapan pajak (tax evasion) diketahui dari 13 pernyataan yang diuji terdapat 12 pernyataan yang valid dan 1 pernyataan yang tidak valid. Dari 13 pernyataan diketahui bahwa pernyataan 11 memiliki $\mathrm{r}_{\text {hitung }}$ lebih rendah dari $r_{\text {tabel }}$ dengan nilai 0,394.

\section{b. Uji Reliabilitas}

Uji reliabilitas ini digunakan untuk menguji konsistensi data dalam jangka waktu tertentu, yaitu untuk mengetahui sejauh mana pengukuran yang digunakan dapat dipercaya atau diandalkan.Karena suatu kuisioner dikatakan reliabel atau handal jika jawaban seseorang terhadap pertanyaan adalah konsisten atau stabil dari waktu ke waktu. Variabel-variabel tersebut dikatakan reliabel apabila cronbach alpha nya memiliki nilai lebih besar 0,70 yang berarti bahwa instrumen tersebut dapat dipergunakan sebagai pengumpul data yang handal yaitu hasil pengukuran relatif koefisien jika dilakukan pengukuran ulang (Ghozali, 2011:132).

Tabel IV.11

Hasil Perhitungan Uji Reliabilitas Instrumen Penelitian

\begin{tabular}{|c|c|c|c|}
\hline & Cronbach & & \\
Variabel & Alpha & $>K$ & Keterangan \\
\hline
\end{tabular}




\begin{tabular}{|l|c|c|c|}
\hline $\begin{array}{l}\text { Ketepatan } \\
\text { Pengalokasian }\end{array}$ & 0,871 & $>$ & Reliabel \\
\hline $\begin{array}{l}\text { Teknologi dan } \\
\text { Informasi } \\
\text { Perpajakan }\end{array}$ & 0,946 & $>$ & Reliabel \\
\hline Diskriminasi & 0,745 & $>$ & Reliabel \\
\hline $\begin{array}{l}\text { Penggelapan } \\
\text { Pajak (Tax } \\
\text { Evasion) }\end{array}$ & 0,873 & $>$ & Reliabel \\
\hline
\end{tabular}

Sumber: Data primer yang diolah, 2017.

\section{Statistik Deskriptif}

Statistik deskriptif digunakan untuk memberikan informasi mengenai karakteristik variabel penelitian yang utama dan daftar demografi responden.Statistik deskriptif digunakan untuk memberikan gambaran atau deskripsi suatu data yang dilihat dari rata-rata (mean), standar deviasi, variance, maksimum, minimum, kurtosis dan skewness (kemencengan data) (Ghozali, 2011:16).

Tabel IV.12

Hasil Statistik Deskriptif

Descriptive Statistics

\begin{tabular}{|l|r|r|r|r|r|}
\hline & N & Min & Max & Mean & $\begin{array}{c}\text { Std. } \\
\text { Deviation }\end{array}$ \\
\hline KETEPATAN & 100 & 20 & 43 & 31.07 & 5.567 \\
PENGALOKASIAN & & & & & \\
TEKNOLOGI DAN & & 30 & 60 & 47.55 & 6.007 \\
INFORMASI & 100 & & & & \\
PERPAJAKAN & 100 & 10 & 34 & 22.96 & 4.997 \\
DISKRIMINASI & 100 & 12 & 37 & 23.41 & 6.173 \\
TAX EVASION & 100 & & & & \\
Valid N (listwise) & & & \\
\hline
\end{tabular}

Sumber: Data primer yang diolah, 2017.

Variabel ketepatan pengalokasian dengan menggunakan 10 item pernyataan dalam kuesioner mempunyai kisaran 20 sampai 43 dengan nilai ratarata sebesar 31,07 dan nilai standar deviasi yang menunjukkan adanya penyimpangan sebesar 5,567 dari nilai rata-rata jawaban responden atas pernyataan tentang ketepatan pengalokasian.
Variabel teknologi dan informasi perpajakan dengan menggunakan 12 item pernyataan dalam kuesioner mempunyai kisaran 30 sampai 60 dengan nilai rata-rata sebesar 47,55 dan nilai standar deviasi yang menunjukkan adanya penyimpangan sebesar 6,007 dari nilai rata-rata jawaban responden atas pernyataan tentang teknologi dan informasi perpajakan.

Variabel diskriminasi dengan menggunakan 9 item pernyataan dalam kuesioner mempunyai kisaran 10 sampai 34 dengan nilai rata-rata sebesar 22,96 dan nilai standar deviasi yang menunjukkan adanya penyimpangan sebesar 4,997 dari nilai rata-rata jawaban responden atas pernyataan tentang diskriminasi.

Variabel penggelapan pajak (tax evasion) dengan menggunakan 12 item pernyataan dalam kuesioner mempunyai kisaran 12 sampai 37 dengan nilai ratarata sebesar 23,41 dan nilai standar deviasi yang menunjukkan adanya penyimpangan sebesar 6,173 dari nilai rata-rata jawaban responden atas pernyataan tentang penggelapan pajak.

\section{Uji Asumsi Klasik}

\section{a. Uji Normalitas Data}

Menurut Ghozali (2011:74-76) uji normalitas bertujuan untuk menguji apakah dalam model regresi, variabel terikat dan variabel bebas keduanya mempunyai distribusi normal ataukah tidak.Model regresi yang baik adalah memiliki distribusi data normal atau mendekati normal.Menentukan normalitas dapat dilakukan dengan uji statistik

Kolmogorov-Smirnov. Jika nilai signifikan > 0,05 maka dapat dikatakan bahwa data berdistribusi normal dan jika nilai signifikan $<0,05$ maka dapat dikatakan bahwa data tidak berdistibusi normal.

Dari hasil uji normalitas data menggunakan uji Kolmogorov-Smirnov (Uji K-S) pada tabel IV.13, dapat dilihat bahwa nilai pada Asymp. Sig. (2-tailed) 
adalah 0,586 yang mana jauh diatas 0,05 . Maka dapat ditarik kesimpulan bahwa data berdistribusi normal.

Tabel IV.13

Uji Normalitas Data Menggunakan Uji

Kolmogorov-Smirnov

One-Sample Kolmogorov-Smirnov Test

\begin{tabular}{|ll|r|}
\hline & & $\begin{array}{r}\text { Unstandard } \\
\text { ized } \\
\text { Residual }\end{array}$ \\
\hline $\mathrm{N}$ & Mean & 100 \\
Normal Parameters ${ }^{\mathrm{a}, \mathrm{b}}$ & Std. \\
& Deviation & 5.13882553 \\
Most Extreme & Absolute & .077 \\
Differences & Positive & .047 \\
Kolmogorov-Smirnov Z & Negative & -.077 \\
Asymp. Sig. (2-tailed) & & .774 \\
\end{tabular}

a. Test distribution is Normal.

\section{b. Uji Multikolonieritas}

Uji multikolonieritas ini bertujuan untuk menguji apakah model regresi ditemukan adanya korelasi antar variabel bebas (independen).Model regresi yang baik seharusnya tidak terjadi korelasi diantara variabel bebas.Untuk mendeteksi ada atau tidaknya multikolonieritas didalam model regresi dilihat dari besaran VIF (Variance Inflation Factor) dan nilai Tolerance.

Tabel IV.14

Uji Multikolonieritas

Coefficients $^{\mathrm{a}}$

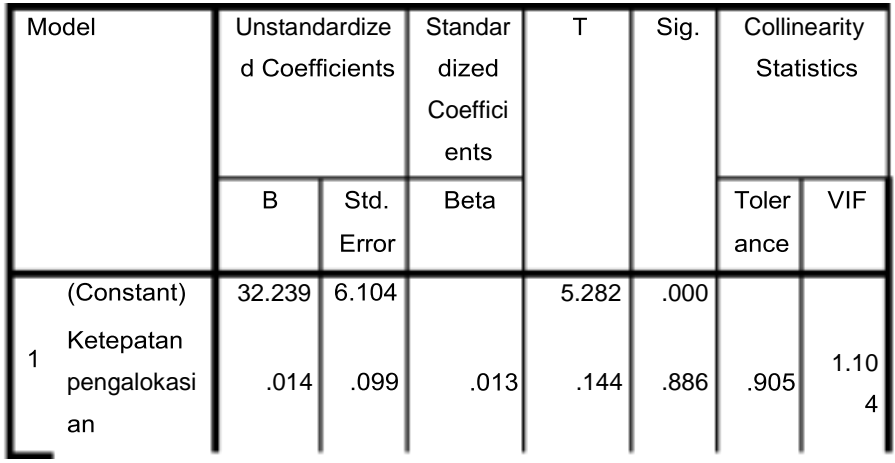

Jurnal Ilmiah Wahana Akuntansi

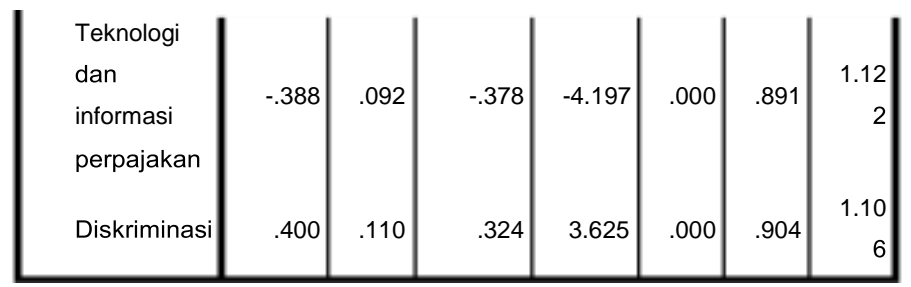

a. Dependent Variable: TAX EVASION

Sumber: Data primer yang diolah, 2017.

Berdasarkan tabel hasil multikolonieritas di atas menunjukkan bahwa masing-masing variabel mempunyai nilai tolerance mendekati angka 1 dan nilai variance inflation factor (VIF) disekitar angka

1. Variabel ketepatan pengalokasian mempunyai nilai tolerance 0,905 dan nilai VIF sebesar 1,104; variabel teknologi dan informasi perpajakan mempunyai nilai tolerance 0,891 dan nilai VIF sebesar 1,122; variabel diskriminasi mempunyai nilai tolerance 0,904 dan nilai VIF sebesar 1,106. Dengan demikian dapat disimpulkan bahwa tidak terdapat multikolonieritas antar variabel independen dalam model regresi di penelitian ini karena nilai tolerance di atas 0,10 dan nilai VIF (variance inflation factor) di bawah 10.

\section{c. Uji Heteroskedastisitas}

Untuk lebih memastikan bahwa tidak terdapat gejala heteroskedastisitas pada model regresi penelitian ini dilakukan uji glejser. Uji glejser dilakukan dengan cara meregresi nilai absolut residual terhadap variabel independen.Hasil uji glejser sebagai berikut:

Tabel IV.15

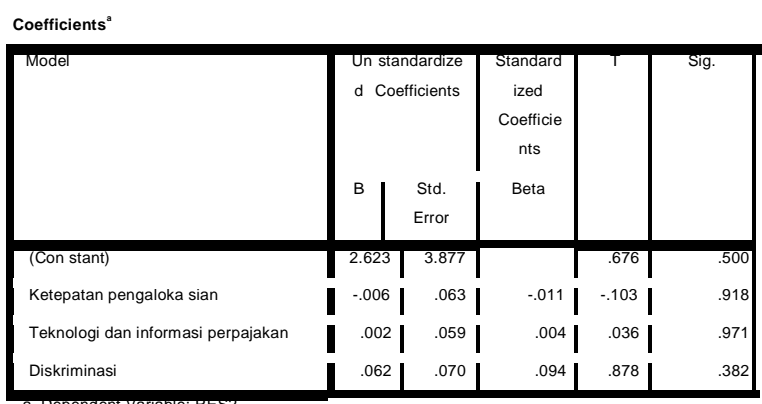

Sumber: Data primer yang diolah, 2017.

Tabel diatas menunjukan bahwa nilai signifikansi variabel ketepatan pengalokasian, teknologi dan informasi perpajakan, dan diskriminasi 
berada diatas tingkat kepercayaan $5 \%$ atau 0,05 yang berarti tidak ada yang signifikan. Dalam uji glejser, jika variabel independen tidak signifikan mempengaruhi variabel dependen berarti tidak terjadi gejala heteroskedastisitas.Dengan begitu, dapat disimpulkan bahwa model regresi dalam penelitian ini terbebas dari masalah heteroskedastisitas.

\section{Analisis Regresi Linier Berganda}

Regresi linear berganda dilakukan untuk mengetahui sejauh mana variabel bebas mempengaruhi variabel terikat. Model ini digunakan untuk menguji apakah ada hubungan sebab akibat antara kedua variabel untuk meneliti seberapa besar pengaruh antara variabel independen, yaitu ketepatan pengalokasian, teknologi dan informasi perpajakan, dan diskriminasi berpengaruh terhadap variabel dependen, yaitu penggelapan pajak (tax evasion).

Adapun persamaan regresinya sebagai berikut:

$Y=32,239+0,014 X_{1}-0,388 X_{2}+0,400 X_{3}+e$

\section{Uji Hipotesis}

a. Uji Signifikansi Parameter Individual (Uji Statistik t)

Uji statistik $\mathrm{t}$ bertujuan untuk mengetahui pengaruh antara variabel independen dengan variabel dependen secara parsial. Untuk mengetahui apakah terdapat pengaruh yang signifikan dari masing-masing variabel independen yaitu ketepatan pengalokasian, teknologi dan informasi perpajakan, dan diskriminasi terhadap satu variabel dependen yaitu penggelapan pajak (tax evasion) maka nilai signifikansi dibandingkan dengan taraf signifikansi sebesar 0,05 .

\begin{tabular}{|c|c|c|c|c|c|}
\hline Model & \multicolumn{2}{|c|}{$\begin{array}{l}\text { Unstandardized } \\
\text { Coefficients }\end{array}$} & $\begin{array}{c}\text { Standardized } \\
\text { Coefficients } \\
\text { Beta }\end{array}$ & $\mathrm{T}$ & Sig. \\
\hline (Constant) & 32.239 & 6.104 & & 5.282 & .000 \\
\hline $\begin{array}{l}\text { Ketepatan } \\
\text { pengalokasian }\end{array}$ & .014 & .099 & .013 & .144 & .886 \\
\hline $\begin{array}{l}\text { Teknologi dan informasi } \\
\text { perpajakan }\end{array}$ & -.388 & .092 & -.378 & -4.197 & .000 \\
\hline Diskriminasi & .400 & .110 & .324 & 3.625 & .000 \\
\hline
\end{tabular}

Tabel IV.17

\section{Hasil Uji Statistik t}

Sumber: Data primer yang diolah, 2017.

Berdasarkan hasil uji t yang disajikan pada tabel IV.17 diatas, dapat dilihat bahwa variabel ketepatan pengalokasian memiliki nilai signifikansi sebesar 0,886 $(>0,05)$ dan nilai $t_{\text {hitung }}<\mathrm{t}_{\text {tabel }}(0,144<$ 1,984). Dengan demikian, maka $\mathrm{H}_{1}$ yang menyatakan bahwa ketepatan pengalokasian berpengaruh terhadap penggelapan pajak di tolak.Sehingga dapat dikatakan bahwa ketepatan pengalokasian tidak berpengaruh signifikan terhadap penggelapan pajak.Oleh karena itu dapat diambil kesimpulan bahwa ketepatan pengalokasian bukan menjadi faktor yang dapat mempengaruhi wajib pajak untuk melakukan ataupun menghindari penggelapan pajak.Hal ini dikarenakan, walaupun menurut responden dalam penelitian ini yaitu wajib pajak orang pribadi yang terdaftar di KPP Pratama Jakarta Sunter rata-rata memiliki jawaban bahwa mereka tidak setuju jika pemerintah sudah mendistribusikan dana yang bersumber dari pajaknya secara merata, adil, maupun transparan, namun penggelapan pajak yang dilakukan oleh wajib pajak tetaplah rendah. Hasil penelitian ini sesuai dengan hasil penelitian yang dilakukan oleh Wahyuningsih (2015) yang menyatakan bahwa ketepatan pengalokasian tidak berpengaruh secara parsial terhadap penggelapan pajak. 
Selain itu pada variabel teknologi dan informasi perpajakan memiliki nilai signifikansi sebesar 0,000 $(<0,05)$ dan nilai $t_{\text {hitung }}>t_{\text {tabel }}(-4,197>1,984)$. Dengan demikian, maka $\mathrm{H}_{2}$ yang menyatakan bahwa teknologi dan informasi perpajakan berpengaruh terhadap penggelapan pajak di terima.Nilai negatif dari $t_{\text {hitung }}$ mengartikan bahwa variabel teknologi dan informasi perpajakan memiliki arah negatif, sehingga dapat disimpulkan bahwa teknologi dan informasi perpajakan berpengaruh negatif dan signifikan terhadap penggelapan pajak.Oleh karena itu dapat diambil kesimpulan bahwa dengan semakin modernnya teknologi dan informasi perpajakan yang telah diterapkan oleh Ditjen Pajak untuk mempermudah wajib pajak dalam melaksanakan kewajiban perpajakannya dapat mengurangi tindakan penggelapan pajak yang akan dilakukan oleh wajib pajak. Hasil penelitian ini sesuai dengan hasil penelitian yang dilakukan oleh Ardyaksa (2014) dan Permatasari (2013) yang menyatakan bahwa teknologi dan informasi perpajakan berpengaruh negatif dan signifikan terhadap penggelapan pajak.

Dan pada variabel diskriminasi memiliki nilai signifikansi sebesar $0,000 \quad(<0,05)$ dan nilai $t_{\text {hitung }}>t_{\text {tabel }}(3,625>1,984)$. Dengan demikian, maka $\mathrm{H}_{3}$ yang menyatakan bahwa diskriminasi berpengaruh terhadap penggelapan pajak diterima.Sehingga dapat dikatakan bahwa diskriminasi berpengaruh positif dan signifikan terhadap penggelapan pajak.Oleh karena itu dapat diambil kesimpulan bahwa masyarakat atau wajib pajak yang menjadi responden dalam penelitian ini berpendapat bahwa dalam hal memenuhi kewajibannya untuk melakukan pembayaran pajak, mereka hampir tidak pernah mengalami perilaku diskriminasi, baik dari segi peraturan perpajakan maupun dari perilaku dan kinerja fiskusnya dalam memberikan pelayanan terhadap para wajib pajak sehingga hal tersebut dapat mengurangi tindakan penggelapan pajak yang akan dilakukan oleh wajib pajak. Hasil penelitian ini sesuai dengan hasil penelitian yang dilakukan oleh Ardi et al (2016) dan Silaen (2015) yang menyatakan bahwa diskriminasi berpengaruh positif terhadap tindakan penggelapan pajak.

\section{b. Uji Signifikansi Simultan (Uji Statistik F)}

Uji statistik $F$ pada dasarnya menunjukkan apakah semua variabel bebas yang dimasukkan dalam model yaitu ketepatan pengalokasian, teknologi dan informasi perpajakan, dan diskriminasi mempunyai pengaruh secara bersama-sama terhadap variabel terikat/dependen yaitu penggelapan pajak (Ghozali, 2011:45).

Dengan derajat kepercayaan 5\%, df 1 (jumlah variabel -1$)=3$, dan df $2(\mathrm{n}-\mathrm{k}-1)$ atau $100-3-1$ $=96$ ( $\mathrm{n}$ adalah jumlah observasi dan $\mathrm{k}$ adalah jumlah variabel independen), hasil diperoleh untuk $F_{\text {tabel }}$ sebesar 2,70. Hasil dari uji statistik F dapat dilihat pada tabel di bawah ini:

Tabel IV.18

Hasil Uji Statistik F

ANOVA $^{\mathrm{a}}$

\begin{tabular}{|l|r|r|r|r|r|}
\hline Model & $\begin{array}{c}\text { Sum of } \\
\text { Squares }\end{array}$ & Df & $\begin{array}{c}\text { Mean } \\
\text { Square }\end{array}$ & F & Sig. \\
\hline $\begin{array}{l}\text { Regress } \\
\text { ion }\end{array}$ & 1157.845 & 3 & 385.948 & 14.172 & $\begin{array}{r}.000 \\
\mathrm{~b}\end{array}$ \\
$\begin{array}{l}\text { Residual } \\
\text { Total }\end{array}$ & $\begin{array}{r}2614.345 \\
3772.190\end{array}$ & $\begin{array}{r}96 \\
99\end{array}$ & 27.233 & & \\
\hline
\end{tabular}

a. Dependent Variable: TAXEVASION

b. Predictors: (Constant), DISKRIMINASI, KETEPATAN

PENGALOKASIAN, TEKNOLOGI DAN INFORMASI PERPAJAKAN

Sumber: Data primer yang diolah, 2017.

Hasil dalam penelitian ini diperoleh signifikan F sebesar 0,000 $(<0,05)$. Selain itu, nilai $F_{\text {tabel }}<F_{\text {hitung }}$ $(2,70<14,172)$. Dengan demikian, $H_{a}$ diterima dan $\mathrm{H}_{\mathrm{o}}$ ditolak, ini berarti menyatakan bahwa ketepatan pengalokasian, teknologi dan informasi perpajakan, dan diskriminasi mempunyai pengaruh secara 
bersama-sama terhadap penggelapan pajak (tax evasion).

c. Uji Koefisien Determinasi (Adjusted $\mathbf{R}^{\mathbf{2}}$ )

Koefisien determinasi pada intinya mengukur seberapa jauh kemampuan model dapat menjelaskan variasi variabel dependen.Pada pengujian hipotesis pertama koefisien determinasi dilihat dari besarnya nilai (Adjusted $R^{2}$ ) untuk mengetahui seberapa jauh variabel bebas yaitu ketepatan pengalokasian, teknologi dan informasi perpajakan, dan diskriminasi serta pengaruhnya terhadap penggelapan pajak (tax evasion). Hasil dari uji koefisien determinasi dapat dilihat pada tabel di bawah ini:

\section{Tabel IV.19}

Hasil Uji Koefisien Determinasi Model Summary

\begin{tabular}{|l|r|r|r|r|}
\hline Model & \multicolumn{1}{|c|}{$\mathrm{R}$} & $\begin{array}{c}\mathrm{R} \\
\text { Square }\end{array}$ & $\begin{array}{r}\text { Adjusted } \\
\mathrm{R} \text { Square }\end{array}$ & $\begin{array}{r}\text { Std. Error of } \\
\text { the Estimate }\end{array}$ \\
\hline 1 & $.554^{\mathrm{a}}$ & .307 & .285 & 5.219 \\
\hline
\end{tabular}

a. Predictors: (Constant), DISKRIMINASI,

KETEPATAN PENGALOKASIAN, TEKNOLOGI DAN

INFORMASI PERPAJAKAN

b. Dependent Variable: TAXEVASION

Sumber: Data primer yang diolah, 2017.

Berdasarkan tabel di atas, maka dapat diketahui bahwa nilai adjusted $\mathrm{R}^{2}$ sebesar 0,285. Dengan demikian, dapat diartikan bahwa $28,5 \%$ dari penggelapan pajak dipengaruhi oleh variabel-variabel independen dalam penelitian ini. Sedangkan sisanya $(100 \%-28,5 \%=71,5 \%)$ dijelaskan oleh variabel lain yang tidak dimasukkan dalam model penelitian ini.

\section{BAB V}

\section{KESIMPULAN, IMPLIKASI, DAN SARAN}

\section{A. Kesimpulan}

Berdasarkan pada data yang telah dikumpulkan dan pengujian yang telah dilakukan dengan menggunakan model regresi berganda,maka kesimpulan yang dapat diambil diantaranya sebagai berikut:
1. Ketepatan pengalokasian $\left(\mathrm{X}_{1}\right)$ tidak berpengaruh signifikan terhadap penggelapan pajak (tax evasion) (Y). Dengan demikian dapat disimpulkan bahwa ketepatan pengalokasian bukan menjadi faktor yang dapat mempengaruhi wajib pajak untuk melakukan ataupun menghindari penggelapan pajak.

2. Teknologi dan informasi perpajakan $\left(X_{2}\right)$ berpengaruh dan signifikan terhadap penggelapan pajak (tax evasion) (Y). Terdapat pengaruh negatif dan signifikan antara teknologi dan informasi perpajakan terhadap penggelapan pajak, artinya semakin baik dan modernnya teknologi dan informasi perpajakan yang diterapkan oleh Ditjen Pajak untuk mempermudah WP dalam melaksanakan kewajiban perpajakannya maka hal ini dapat mengurangi tindakan penggelapan pajak yang akan dilakukan oleh wajib pajak, begitupun sebaliknya.

3. Diskriminasi $\left(\mathrm{X}_{3}\right)$ berpengaruh terhadap penggelapan pajak (tax evasion) (Y). Terdapat pengaruh positif dan signifikan antara diskriminasi terhadap penggelapan pajak, artinya semakin rendah tingkat diskriminasi menurut wajib pajak dalam hal perpajakan, maka semakin rendah pula tindakan penggelapan pajak yang akan dilakukan oleh wajib pajak, begitupun sebaliknya.

\section{B. Implikasi}

Dari penelitian yang telah dilakukan, terdapat implikasi penelitian yang dapat diambil, diantaranya:

1. Penerimaan dana yang berasal dari pajak jika menurut wajib pajak tidak dialokasikan dengan tepat oleh pemerintah dan wajib pajak tidak merasakan adanya manfaat dari pajak yang telah ia bayarkan selama ini, maka hal tersebut akan menyebabkan tingkat perilaku penggelapan pajak semakin meningkat. Dengan melihat fakta 
tersebut, maka pemerintah harus lebih baik dalam mengawasi serta mengalokasikan dana pajak yang ada secara benar dan tepat serta transparan kepada masyarakat sehingga wajib pajak merasakan adanya manfaat yang bisa ia dapatkan dari pembayaran pajak tersebut. Dengan begitu diharapkan tingkat kecenderungan wajib pajak untuk melakukan penggelapan pajak bisa semakin menurun.

2. Dengan semakin baik dan modernnya teknologi dan informasi perpajakan yang diterapkan oleh Ditjen Pajak dapat membuat wajib pajak merasa dipermudah dalam hal melakukan kewajiban perpajakannya, sebab wajib pajak tidak perlu lagi melakukan segala kegiatan perpajakannya dengan mendatangi langsung KPP setempat sehingga wajib pajak dapat lebih menghemat waktu dan juga tenaga. Selain itu dengan semakin modernnya teknologi dan informasi perpajakan, wajib pajak semakin sulit untuk memanipulasi data perpajakannya. Dengan melihat fakta tersebut, maka Ditjen Pajak harus terus melakukan modernisasi pelayanan perpajakannya agar wajib pajak semakin merasa puas dalam melaksanakan kewajiban perpajakannya sehingga diharapkan hal tersebut dapat menurunkan kecenderungan wajib pajak untuk melakukan penggelapan pajak.

3. Diskriminasi yang dirasakan oleh wajib pajak, baik dalam hal peraturan perpajakan maupun pelayanan perpajakan dapat membuat wajib pajak merasa diperlakukan secara tidak adil oleh pemerintah sehingga kecenderungan wajib pajak untuk melakukan penggelapan pajak semakin tinggi. Dengan melihat fakta tersebut, maka pemerintah dalam hal ini Ditjen Pajak harus lebih meminimalisir peraturan perpajakan yang dapat dianggap mendiskriminasi terhadap suatu golongan tertentu agar tidak ada wajib pajak yang merasa diperlakukan secara tidak adil oleh pemerintah, dengan begitu dapat menurunkan kecenderungan wajib pajak untuk melakukan penggelapan pajak.

\section{Saran}

Berdasarkan hasil penelitian yang ada, maka saran-saran yang dapat diberikan adalah sebagai berikut:

1. Penelitian selanjutnya

Diharapkan bisa menambahkan jumlah variabel independen yang dapat mempengaruhi penggelapan pajak, seperti self assessment system, kecenderungan personal, tax morale, dan keadilan pajak.

2. KPP Pratama Jakarta Sunter

Diharapkan dapat meningkatkan pelayanan yang diberikan sehingga dapat juga meningkatkan kesadaran wajib pajak untuk melakukan kewajiban perpajakannya secara sukarela sehingga wajib pajak tidak melakukan tindakan tax evasion.

3. Pemerintah

Diharapkan pemerintah dapat melakukan sosialisasi sedari dini tentang pentingnya sikap wajib pajak untuk taat dan patuh dalam melakukan kewajiban perpajakannya.Disamping itu juga perlu disosialisasikan secara lebih luas manfaat dari uang pajak yang telah disetorkan ke kas negara.Diharapkan dengan semakin tinggi kesadaran masyarakat membayar pajak, maka kecenderungan untuk melakukan pelanggaran dan tindakan tax evasion semakin menurun.

\section{DAFTAR PUSTAKA}

Agoes, Sukrisno dan Esterlita Trisnawati. 2013.

"Akuntansi Perpajakan Edisi 3"

Jakarta: Salemba Empat.

Ardi, Devi Marta. 2016. "Pengaruh Persepsi Wajib Pajak Orang PribadiTerhadap Tindakan 
Penggelapan Pajak Di Kota Surakarta”. Journal ofEconomic and Economic Education Vol.4 No.2 (177 -191). Surakarta:Universitas Islam Batik Surakarta.

Ardyaksa, Theo Kusuma dan Kiswanto. 2014. "Pengaruh Keadilan, Tarif Pajak,Ketepatan Pengalokasian, Kecurangan, Teknologi dan Informasi Perpajakan Terhadap Tax evasion". Accounting Analysis Journal 3 (4) Hal475-484. Semarang: Universitas Negeri Semarang.

Armina, Eka Nilam dan Afrizal Tahar. 2016. "Pengaruh Keadilan, Diskriminasi,Tarif Pajak, Ketepatan Pengalokasian, Teknologi dan Informasi Perpajakan Terhadap Tindakan Tax Evasion". Jurnal. Yogyakarta: Universitas Muhammadiyah Yogyakarta.

Ayu, S. D. dan R. Hastuti. 2009. "Persepsi Wajib Pajak: Dampak PertentanganDiametral Pada Tax Evasion Dalam Aspek Kemungkinan Terdeteksinya Kecurangan, Keadilan, Ketepatan Pengalokasian, Teknologi SistemPerpajakan, dan Kecenderungan Personal (Studi Wajib Pajak OrangPribadi)”.Kajian Akuntansi, Vol. 1 No. 1. Hal 1-12. Semarang: UNIKA Soegijapranata.

Bahasyim Assifie Jadi Nasabah Prioritas BNI.

2010.http://www.rmol.co/read/2010/10/09/6009/

$\underline{\text { Bahasyim-Assifie-Jadi }}$

-Nasabah-Prioritas-BNI-. Diakses pada 17

Februari 2017.

Fadillah. 2012. "Psikologi Perkembangan I".

Pusat Belajar dan $e$ -

learning.http://www.mercubuana.ac.id

Friskianti, Yossi. 2014. “ PengaruhSelf Assessment System, Keadilan,
TeknologiPerpajakan, dan Ketidakpercayaan Kepada Pihak Fiskus Terhadap Tindakan Tax evasion". Accounting Analysis Journal 3 (4) Hal 543-552. Semarang: Universitas Negeri Semarang.

Gelapkan Pajak, Asian Agri Dihukum Denda Rp.

Triliun.

2012.http://www.mongabay.co.id/2012/12/28/gel apkan-pajak-asian-agri

dihukum-denda-rp25-triliun/. Diakses pada 17

Februari 2017.

Gelapkan Uang Klien, Konsultan Pajak Jadi

Tersangka.

2014.http://news.detik.com/berita/2461041/gelap kan-uang-klien-konsultan pajak-jadi-tersangka. Diakses pada 27 Maret 2017.

Ghozali, Imam. 2001. “Aplikasi Analisis Multivariate dengan Program SPSS".Semarang: UNDIP.

Handyani, Annisa'ul dan Nur Cahyonowati.

2014. "Analisis Faktor-Faktor Yang Mempengaruhi Persepsi Wajib Pajak Mengenai Penggelapan Pajak".Diponegoro Journal Of Accounting Vol. 3 No. 3 Hal 1-7. Semarang:UNDIP.

Hasanah, Nuramalia dan Indra Pahala. 2015. "Manajemen Pajak". Jakarta:Lembaga Pengembangan Pendidikan UNJ.

Indriyani, Mila. 2016. "Pengaruh Keadilan, Sistem Perpajakan, Diskriminasi, DanKemungkinan Terdeteksinya Kecurangan Terhadap Persepsi Wajib PajakOrang Pribadi Mengenai Perilaku Tax Evasion”. Seminar 
NasionalIENACO. Surakarta: Universitas Islam

Batik Surakarta.

Izza, Ika Alfi Nur Dan Ardi Hamzah. 2009.

"Etika Penggelapan Pajak PerspektifAgama:

Sebuah Studi Interpretatif".

Jatmiko, Agus Nugraha. 2006. "Pengaruh Sikap Wajib Pajak Pada Pelaksanaan Sanksi Denda, Pelayanan Fiskus Dan Kesadaran Perpajakan TerhadapKepatuhan Wajib Pajak". Tesis.

Semarang: Universitas Diponegoro.

Mardiasmo. 2011. "Perpajakan Edisi Revisi". Yogyakarta: Penerbit Andi.

Ngadiman. 2008. "Modernisasi dan Reformasi Pelayanan Perpajakan". MIIPS Vol.7 No.2 September 2008 Hal 165-175

Pandiangan, Liberti. 2007. "Modernisasi dan Reformasi Pelayanan Perpajakan”. Elex Media Komputindo.

Pedoman Penulisan Skripsi Sarjana Ekonomi. 2012. FE: UNJ

Permatasari, Inggrid. 2013. "Meminimalisasi Tax Evasion Melalui Tarif Pajak,Teknologi dan Informasi Perpajakan, Keadilan Sistem Perpajakan, danKetepatan Pengalokasian Pengeluaran Pemerintah (Studi Empiris pada Wajib Pajak Orang Pribadi di Wilayah KPP Pratama Pekanbaru Senapelan). Diponegoro Journal Of Accounting Vol. 2 No. 2 Hal 1-10. Semarang: UNDIP.

Resmi, Siti. 2011. "Perpajakan: Teori dan Kasus”. Jakarta: Salemba Empat.
Robbins, Stephan P. dan Timothy A. Judge. 2008.

Perilaku Organisasi. Jakarta:Salemba Empat

Sariani, Putu et al. 2016. "Pengaruh Keadilan, Sistem Perpajakan, Diskriminasi,Dan Biaya Kepatuhan Terhadap Persepsi Wajib Pajak Mengenai EtikaPenggelapan Pajak (Tax Evasion) Pada KPP Pratama Singaraja”. JurnalAkuntansi Program S1 Vol. 6 No. 3. Singaraja: Universitas Pendidikan

Ganesha.

Silaen, Charles. 2015. "Pengaruh Sistem Perpajakan, Diskriminasi, TeknologiDan Informasi Perpajakan Terhadap Persepsi Wajib Pajak Mengenai EtikaPenggelapan Pajak (Tax Evasion)". Jom FEKON Vol. 2 No. 2 Hal 1-15.

Pekanbaru: Universitas Riau.

Suandy, Erly. 2001. "Perencanaan Pajak". Jakarta: Salemba Empat.

Suandy, Erly. 2009. "Hukum Pajak". Jakarta: Salemba Empat.

Sugiyono. 2011. "Statistika Untuk Penelitian". Bandung: Penerbit ALFABETA

Syahrina, Pratomo dan Dudi Pratomo. 2014. "Pengaruh KemungkinanTerdeteksinya Kecurangan, Keadilan Pajak, Ketepatan PengalokasianPajak, dan Teknologi Sistem Perpajakan Terhadap Tax Evasion OlehWajib Pajak”. SNEB. Bandung: Universitas Telkom.

Tahun lalu jumlah kasus pajak meningkat 280 persen.2015.

http://www.cnnindonesia.com/ekonomi/2015012 9071636-78-28176/tahun-lalu-jumlah-kasus- 
pajak-meningkat-280-persen/. Diakses pada 21

Februari 2017

Yolanda, Dera et al. 2016. "Pengaruh Sistem Perpajakan, Diskriminasi,Kemungkinan

Terdeteksinya Kecurangan, dan Norma Terhadap PersepsiWajib Pajak Mengenai Penggelapan Pajak (Tax Evasion). Jurnal.Universitas Bung Hatta.

Wahyuningsih, Dian Tri. 2015. "Minimalisasi Tax Evasion Melalui Tarif Pajak,Teknologi Dan Informasi Perpajakan, Keadilan Sistem Perpajakan,Dan Ketepatan Pengalokasian Pengeluaran Pemerintah". Jurnal.Semarang: Universitas Dian Nuswantoro Semarang.

Zain, Mohammad. 2008. "Manajemen Perpajakan Edisi 3”. Jakarta: SalembaEmpat. 